\title{
THE ISOLATION OF PLASMIDS CONTAINING DNA COMPLEMENTARY TO MESSENGER RNA FOR VARIANT SURFACE GLYCOPROTEINS OF Trypanosoma brucei
}

(Recombinant DNA; in vitro translation; antigenic variation; $\operatorname{poly}(\mathrm{A})^{+} \mathrm{RNA}$; complementary DNA clones)

\author{
J.H.J. HOEIJMAKERS*, P. BORST, J. VAN DEN BURG, C. WEISSMANN** and \\ G.A.M. CROSS***
}

Section for Medical Enzymology and Molecular Biology, Laboratory of Biochemistry, University of Amsterdam, Jan Swammerdam Institute, P.O. Box 60.000, 1005 GA Amsterdam (The Netherlands), **Institut für Molekularbiologie I, Universität Zürich, Honggerberg, 8093 Zürich (Switzerland), and ***The Wellcome Research Laboratories, Department of Immunochemistry, Langley Court, Beckenham, Kent BR3 3BS (U.K.)

(Received November 20th, 1979)

(Accepted December 3rd, 1979)

\section{SUMMARY}

We have isolated poly $(\mathrm{A})^{+} \mathrm{RNA}$ from four antigenic variants $(117,118,121$, 221) of one clone of Trypanosoma brucei. Translation of these poly $(\mathrm{A})^{+}$ RNAs in a rabbit reticulocyte lysate gave rise to proteins that could be precipitated with antisera against homologous variant surface glycoprotein, the protein responsible for antigenic variation in trypanosomes. From the electrophoretic mobility of these in vitro products in sodium dodecyl sulphate (SDS) gels we infer that variant surface glycoproteins (VSGs) are made as pre-proteins, which require trimming to yield mature VSGs.

The total translation products from the four poly $(\mathrm{A})^{+} \mathrm{RNAs}$ produced a complex set of bands on SDS gels, which only differed in the region where the variant pre-glycoproteins migrated. The only detectable variation in the messenger RNA populations of these variants is, therefore, in the messenger RNA for variant pre-glycoproteins.

We have made duplex DNA copies of these poly $(\mathrm{A})^{+}$RNAs, linked the complementary DNA to plasmid pBR322 by GC tailing and cloned this recombinant DNA in Escherichia coli. Colony hybridization with complementary DNA made on poly $(\mathrm{A})^{+}$RNA showed that $7-10 \%$ of the colonies con-

*Present address: Laboratory of Medical Microbiology, Mauritskade 57, Amsterdam (The Netherlands)

Abbreviations: bp, base pairs; cDNA, complementary DNA; DBM paper, diazobenzyloxymethyl-cellulose paper; kd, kilodaltons; rRNA, ribosomal RNA; SDS, sodium dodecyl sulphate; VSG, variant surface glycoprotein. 
tained DNA that hybridized only with the homologous probe. Plasmid DNA was isolated from ten such colonies (two or three of each variant complementary DNA), bound to diazobenzyloxymethyl-cellulose (DBM) paper and used to select complementary messenger RNA from total poly( $\mathrm{A})^{+} \mathrm{RNA}$ by hybridization. In eight cases the RNA recovered from the filter gave variant pre-glycoprotein as the predominant product of in vitro translation.

Poly $(\mathrm{A})^{+}$RNA from each of the variants only hybridized to the homologous complementary DNA in filter hybridizations. Each trypanosome variant, therefore, contains no detectable messenger RNAs for the three heterologous variant-specific glycoproteins tested. We conclude from this lack of crosshybridization that antigenic diversity in trypanosomes, unlike antibody diversity in mammals, does not involve the linkage of a repertoire of genes for the variable $\mathrm{N}$-terminal half to a single gene for the $\mathrm{C}$-terminal half of the VSGs.

\section{INTRODUCTION}

Trypanosomes are unicellular parasitic flagellates, responsible for tropical diseases such as sleeping sickness in man. In the successful adaptation to life in the mammalian bloodstream, T. brucei and related trypanosomes have evolved an ingenious and biochemically interesting mechanism to cope with the immune response of the host. This defense consists of "antigenic variation", i.e. the ability to vary the surface coat, the only part of the trypanosome exposed to the host (reviewed in Gray (1965); Vickerman (1978); Cross (1978)). The number of immunologically different surface coat types that one trypanosome can make is not known, but exceeds 100 (Capbern et al., 1977; Cross, 1978); it could be unlimited.

The molecular basis of antigenic variation has been clarified in recent years. The surface coat consists of a single glycoprotein with a molecular weight of about 65000 (Cross, 1975). VGSs from different trypanosome variants differ in amino acid composition, conformational features and $\mathrm{N}$-terminal amino acid sequences (Bridgen et al., 1976; Johnson and Cross, 1979). Antigenic variation is, therefore, due to the ability of the trypanosome to produce a large repertoire of VSGs that differ sufficiently in amino acid sequence to have no antigenic determinants in common.

A major question that remains is how one trypanosome clone can produce so many different VSGs. In principle three types of mechanism can be envisaged: (1) alteration of a limited number of genes by mutation, sequence reassortment. etc.; (2) reassortment of sequences from a limited number of genes at the RNA level by differential splicing of long precursors; (3) differential expression of a large series of different genes.

These three mechanisms can be distinguished by sequence studies on VSG genes and their transcripts. As a first step in these studies we have cloned DNA complementary to VSG messenger RNA (mRNA). It has previously been shown 
that poly (A) ${ }^{+}$RNA from bloodstream $T$. brucei contains a major mRNA of about 2000 nucleotides that can be translated in vitro to yield a protein that resembles the homologous VSG (Eggitt et al., 1977; Williams et al., 1978; Lheureux et al., 1979). We have used poly(A) ${ }^{+} \mathrm{RNA}$ from four $T$. brucei variants, each making a different VSG, as template to make complementary DNA (cDNA), linked the four cDNA preparations to plasmid pBR322 and cloned the recombinant DNA in $E$. coli. To identify colonies containing DNA complementary to VSG mRNA we have used the differential colony hybridization technique first used by St. John and Davis (1979) to identify colonies containing DNA complementary to mRNAs present in induced but not in uninduced cells. The principle is that such colonies will only hybridize with mRNA from induced cells and remain negative with RNA from uninduced cells.

In our case this approach involves three assumptions: First, we assume that variant A only contains the mRNA for VSG A and not also in cryptic form the mRNAs for VSGs B-Z. Second, we assume that the main difference in the mRNA populations isolated from the four variants will be in the mRNAs for the VSGs. Third, we assume that the mRNAs for different VSGs differ sufficiently to have little or no sequence homology. Hence, cDNA clones containing DNA complementary to VSG mRNA should hybridize predominant ly or exclusively to homologous poly $(\mathrm{A})^{+}$RNA but not to RNA from the three other variants.

In this paper we report the successful outcome of this approach and present a preliminary characterization of the clones obtained.

\section{MATERIALS AND METHODS}

\section{(a) Solutions}

Composition of solutions referred to in the text are as follows. NET-X: 100 $\mathrm{mM} \mathrm{NaCl}, \mathrm{X} \mathrm{mM}$ Na-EDTA, $10 \mathrm{mM}$ Tris - $\mathrm{HCl}$ (pH 8.0). SET: $150 \mathrm{mM} \mathrm{NaCl}$, $1 \mathrm{mM} \mathrm{Na-EDTA}, 30 \mathrm{mM}$ Tris $\cdot \mathrm{HCl}$ ( $\mathrm{pH} 8.0$ ). TNE: $100 \mathrm{mM} \mathrm{NaCl}, 5 \mathrm{mM}$ Na-EDTA, $50 \mathrm{mM}$ Tris $\cdot \mathrm{HCl}(\mathrm{pH}$ 7.5). SSC: $150 \mathrm{mM} \mathrm{NaCl}, 15 \mathrm{mM}$ Na-citrate (pH 7.0). Denhardt solution: Ficoll, polyvinylpyrrolidone and bovine serum albumin, $0.02 \% \mathrm{w} / \mathrm{v}$ each (Denhardt, 1966).

\section{(b) Growth of trypanosomes}

The cloning of antigenic variants of a cloned line of $T$. brucei, strain 427 , was done as described by Cross (1975). We have used the clones Molteno Institute Trypanozoon antigen type (MITat) 1.2 (221), 1.4 (117), 1.5 (118) and $1.6(121)$. The numbers between brackets designate the old names of these clones and for convenience these are used in this paper rather than the new conventional nomenclature. Clone 221 is described by Johnson and Cross (1979), the others by Cross (1975). Large batches of trypanosomes were grown in Wistar rats starting from stabilates kept in liquid nitrogen (Opperdoes et al., 1976). Trypanosomes were checked for surface antigen 
homogeneity by immunofluorescence of ethanol-fixed (Aarden et al., 1975) or formalin-fixed (cf. Nantulya and Doyle, 1977) smears. More than 95\% of all trypanosomes bound the variant-specific homologous antibody. Trypanosomes were purified from blood elements and washed as described by Fairlamb et al. (1978).

\section{(c) Antigens and antisera}

Purified surface coat glycoproteins of the variants used and the corresponding antisera were prepared essentially as described by Cross (1975).

\section{(d) Isolation of poly $(A)^{+} R N A$}

For the isolation of total cell RNA a modification of the hot phenol extraction procedure of Penman (1966) was used. The pelleted, washed trypanosomes ( $1-3 \mathrm{~g}$ wet wt.) were dissolved in $5 \mathrm{ml}$ of NET-100 per $\mathrm{g}$ of trypanosomes (wet wt.) and lysed by the addition of an equal volume of a detergent mix in the presence of 20 units heparin per $\mathrm{ml}, 0.05 \%$ Macaloid and $0.2 \%$ diethyl pyrocarbonate to prevent ribonuclease action. The detergent mix consisted of $4 \%$ SDS, $2 \%$ triisopropylnaph thalene sulphonate, $8 \%$-aminosalicylate, $6 \%$ butanol-2 in NET-100 (Kleisen et al., 1975). After vigorous shaking for $1 \mathrm{~min}$ at $0^{\circ} \mathrm{C}, 1 \mathrm{vol}$. of phenol-cresol-8-hydroxyquinoline (1000:120:1) was added and shaking was continued for 5 min at $4^{\circ} \mathrm{C}$ followed by $10 \mathrm{~min}$ at $65^{\circ} \mathrm{C}$. An equal volume of chloroform-isoamylalcohol (100:1) was added and extraction was again for $10 \mathrm{~min}$ at $65^{\circ} \mathrm{C}$. The mixture was centrifuged for $15 \mathrm{~min}$ at $5000 \mathrm{rev} . / \mathrm{min}$ in the Sorvall HB-4 rotor at room temperature. The water phase and the usually voluminous interphase were combined and a second extraction followed with 1 vol. of chloroform-isoamylalcohol for $10 \mathrm{~min}$ at $65^{\circ} \mathrm{C}$. Centrifugation and extraction were repeated once. Usually after the third extraction the interphase had disappeared and the nucleic acids in the viscous aqueous phase were precipitated with 2.5 vol. ethanol overnight at $-20^{\circ} \mathrm{C}$. The nucleic acid pellet was washed twice with $70 \%$ ethanol, dissolved in $10 \mathrm{mM}$ Tris $\cdot \mathrm{HCl}(\mathrm{pH} 7.5), 10 \mathrm{mM} \mathrm{MgCl}_{2}$ and treated for $20 \mathrm{~min}$ at $27^{\circ} \mathrm{C}$ with $10 \mu \mathrm{g}$ deoxyribonuclease per ml (Sigma, made ribonuclease-free by purification over a cUMP column (Maxwell et al., 1977)). A 30 -min incubation at $37^{\circ} \mathrm{C}$ with $5 \mu \mathrm{g}$ pronase per $\mathrm{ml}$ (pretreated for $2 \mathrm{~h}$ at $37^{\circ} \mathrm{C}$ and $10 \mathrm{~min}$ at $80^{\circ} \mathrm{C}$ ) and $0.1 \%$ SDS followed and the mixture was deproteinized by phenol extraction. After centrifugation the aqueous phase was made $0.5 \mathrm{M}$ in $\mathrm{NaCl}$ and applied onto an oligo(dT)-cellulose column (Sigma, type 7B). The poly (A) ${ }^{+}$RNA fraction retained on the column after two cycles of application of the total RNA was washed with 30 column volumes of $10 \mathrm{mM}$ Tris $\cdot \mathrm{HCl}, 10 \mathrm{mM}$ EDTA, $0.5 \mathrm{M} \mathrm{NaCl}, 0.1 \% \operatorname{SDS}(\mathrm{pH} 7.6)$ and eluted with 4 vol. of $1 \mathrm{mM}$ Tris $\cdot \mathrm{HCl}, 1 \mathrm{mM}$ EDTA, $0.1 \%$ SDS (pH 7.6). Eluted RNA was briefly heated to $65^{\circ} \mathrm{C}$ for $5 \mathrm{~min}$, made $0.4 \mathrm{M}$ in $\mathrm{NaCl}$ and reapplied to the same column. The washing and elution procedures were repeated and the poly $(\mathrm{A})^{+} \mathrm{RNA}$ was precipitated with ethanol. 


\section{(e) Cell-free protein synthesis}

RNA was translated in vitro in an extract derived from a rabbit reticulocyte lysate, treated with Micrococcus nuclease according to Pelham and Jackson (1976). $25-\mu \mathrm{l}$ incubations $\left(1.5 \mathrm{~h}\right.$ at $\left.37^{\circ} \mathrm{C}\right)$ contained $2 \mu \mathrm{g}$ of poly $(\mathrm{A})^{+} \mathrm{RNA}$ and $25-50 \mu \mathrm{Ci}$ of $\left[{ }^{35} \mathrm{~S}\right]$ methionine $(\mathrm{NEN} ; 550 \mathrm{Ci} / \mathrm{mmol}$, or The Radiochemical Center; approx. $1000 \mathrm{Ci} / \mathrm{mmol})$. Total $\left[{ }^{35} \mathrm{~S}\right]$ methionine incorporation was determined by precipitation with trichloroacetic acid, as described by Pawson et al. (1976). Usually a 15- to 35-fold stimulation was obtained compared to endogenous activity. Immunoprecipitation with formalin-fixed Staphylococcus aureus cells (Kessler, 1975) [obtained from Mr. F.J. van Hemert, Laboratory of Physiological Chemistry, State University Leiden] was as described by Paucha et al. (1978) with minor modifications.

\section{(f) Gel electrophoresis of proteins}

Samples were dissolved in a buffer containing $7 \mathrm{M}$ urea, $100 \mathrm{mM}$ Tris $\cdot \mathrm{HCl}$ (pH 6.8), $2 \%$ SDS, $5 \% \beta$-mercaptoethanol and boiled for $1 \mathrm{~min}$ at $100^{\circ} \mathrm{C}$ before layering on a $15 \%$ poly acrylamide SDS gel (Laemmli, 1970). After electrophoresis $(12-16 \mathrm{~h}$ at $125 \mathrm{~V}, 12.5 \mathrm{~V} / \mathrm{cm})$ gels were stained with Coomassie Brilliant Blue, dried and subjected to autoradiography with Kodak $\mathrm{X}$-ray film. The proteins used as molecular weight standards are: phosphorylase $\alpha(94 \mathrm{kd})$, bovine serum albumin (68 kd), ovalbumin ( $43 \mathrm{kd})$, lactate dehydrogenase $(36 \mathrm{kd})$, carbonic anhydrase $(26 \mathrm{kd})$ and cytochrome $c(12 \mathrm{kd})$.

\section{(g) Restriction enzyme digestions}

The source of endonuclease PstI and the digestion conditions used were as described by Weislogel et al. (1977).

\section{(h) Gel electrophoresis of nucleic acids}

Electrophoresis of DNA in $0.6 \%$ or $2.0 \%$ horizontal agarose gels under neutral or alkaline conditions were as described by McDonell et al. (1977). Molecular weight markers are described in the text.

\section{(i) Transfer of nucleic acids to nitrocellulose filters}

Restriction-fragmented DNA, separated on gels was denatured with alkali and blotted onto nitrocellulose filters essentially as described by Southern (1975).

\section{(j) Preparation of labelled probes}

Double-stranded DNA was labelled by nick-translation (Rigby et al., 1977) to a specific activity of $10-50 \cdot 10^{6}{ }^{32} \mathrm{P} \mathrm{cpm} / \mu \mathrm{g}$ using $\left[\alpha-{ }^{32} \mathrm{P}\right] \mathrm{dATP}$ and $\left[\alpha-{ }^{32} \mathrm{P}\right]$ dTTP (The Radiochemical Center; specific activity $2-3 \mathrm{Ci} / \mu \mathrm{mol}$ ) as the labelled deoxynucleotides. Highly labelled cDNA probes $\left(>10^{8}{ }^{32} \mathrm{P} \mathrm{cpm} /\right.$ $\mu \mathrm{g})$ were made from poly $(\mathrm{A})^{+} \mathrm{RNA}$ using conditions similar to those given for the "first strand synthesis" below, except that the concentrations of the labelled deoxynucleotides $\left(\left[\alpha-{ }^{32} \mathrm{P}\right] \mathrm{dCTP},\left[\alpha-{ }^{32} \mathrm{P}\right] \mathrm{dATP}\right.$ or $\left.\left[\alpha-{ }^{32} \mathrm{P}\right] \mathrm{dTTP}\right)$ were 
$7.5 \mu \mathrm{M}$ instead of $1 \mathrm{mM}$. To reach this concentration, half the amount of unlabelled equivalent was added. Under these conditions $\mathrm{cDNA}$ with a mean length of 200-500 nucleotides was synthesized as determined by alkaline gel electrophoresis. Partial fragmentation with alkali and labelling of the fragmented RNA by polynucleotide kinase and $\left[\gamma^{3}{ }^{32} \mathrm{P}\right] \mathrm{dATP}$ (The Radiochemical Center; specific activity $>3 \mathrm{Ci} / \mu \mathrm{mol}$ ) was as described (Goldbach et al., 1978).

\section{(k) Hybridization with DNA filters}

DNA filters were hybridized as described (Hoeijmakers and Borst, 1978), unless stated otherwise.

\section{(l) Synthesis of double-stranded DNA}

First strand synthesis. cDNA was synthesized under the reaction conditions described by Taniguchi et al. (1978) with minor modifications. The $800-\mu \mathrm{l}$ reaction mixture contained $40 \mathrm{mM}$ Tris $\cdot \mathrm{HCl}(\mathrm{pH} 7.5), 30 \mathrm{mM} \mathrm{NaCl}, 5 \mathrm{mM}$ $\mathrm{MgCl}_{2}, 0.5 \mathrm{mM}$ dithiothreitol, $20 \mu \mathrm{g}$ oligo(dT) per $\mathrm{ml}, 1 \mathrm{mM}$ each of dGTP, dCTP, dTTP and $\left[\alpha{ }^{32} \mathrm{P}\right] \mathrm{dATP}$ (specific activity $10000 \mathrm{cpm} / \mathrm{nmol}$ ), $45 \mu \mathrm{g}$ poly $(\mathrm{A})^{+} \mathrm{RNA}$ and 250 units Avian Myeloblastosis Virus reverse transcriptase (obtained from Dr. J. Beard, Life Sciences Inc., St. Petersburg, FL, USA). After incubation for $80 \mathrm{~min}$ at $37^{\circ} \mathrm{C}$ the reaction was terminated by the addition of neutral EDTA and SDS to final concentrations of $10 \mathrm{mM}$ and $0.1 \%$, respectively. Small aliquots were taken for precipitation with trichloroacetic acid. To the remainder sodium acetate $(\mathrm{pH} 5.6)$ was added to $0.3 \mathrm{M}$ and the mixture was extracted with an equal volume of phenol. The phenol was re-

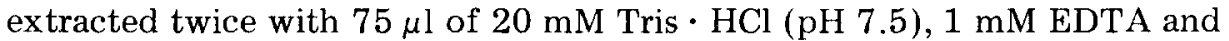
the combined aqueous phases were precipitated with ethanol overnight at $-20^{\circ} \mathrm{C}$. The pellet was washed with $96 \%$ ethanol, dissolved in $20 \mathrm{mM}$ Tris $\cdot \mathrm{HCl}$ (pH 7.5), 1 mM EDTA and chromatographed over a 2-ml Sephadex G-100 column (Pharmacia). Since our Sephadex batches were found to bind in an irreversible fashion over $0.5 \mu \mathrm{g}$ of nucleic acid, columns were "pre-saturated" with $40 \mu \mathrm{g}$ of rat-liver carrier RNA before use. The pooled, excluded fractions were made $0.3 \mathrm{M}$ in sodium acetate $(\mathrm{pH} 5.6)$ and nucleic acids were precipitated overnight at $-20^{\circ} \mathrm{C}$ with ethanol. The washed precipitate was treated with alkali $(0.5 \mathrm{M} \mathrm{NaOH})$ for $10 \mathrm{~min}$ at room temperature to remove the RNA template and after neutralization with acetic acid (0.5 M) directly precipitated with ethanol (Taniguchi et al., 1978). The size of the single-stranded cDNA was determined from its electrophoretic mobility in a $1.5 \%$ alkaline agarose gel relative to marker DNAs of known length.

Second strand synthesis. The single-stranded cDNA $(5.5-7.5 \mu \mathrm{g})$ was made double stranded by incubation with DNA polymerase I (11-15 units: Boehringer) in the presence of $100 \mathrm{mM}$ sodium phosphate (pH 6.9), $10 \mathrm{mM}$ $\mathrm{MgCl}_{2}$ and $10 \mathrm{mM}$ dithiothreitol, $1 \mathrm{mM}$ each of dATP, dGTP and $\left[{ }^{3} \mathrm{H}\right] \mathrm{dTTP}$ (NEN; specific activity $30000 \mathrm{cpm} / \mathrm{nmol}$ ) in a final volume of $55-75 \mu \mathrm{l}$ (Taniguchi et al., 1978). The reaction was allowed to continue for $10 \mathrm{~h}$ at $15^{\circ} \mathrm{C}$. Termination of the reaction and further treatment were as above for the 
"first strand synthesis", omitting the first ethanol precipitation and the alkali treatment.

$S_{1}$ nuclease digestion of double-stranded $c D N A$. Double-stranded cDNA $(7.5-11 \mu \mathrm{g})$ was treated with $S_{1}$ nuclease (prepared according to Wiegand et al., 1975) in a 200- $\mu 1$ incubation mixture containing $0.2 \mathrm{M} \mathrm{NaCl}, 50 \mathrm{mM}$ sodium acetate ( $\mathrm{pH} 4.5), 1 \mathrm{mM} \mathrm{ZnSO}_{4}$. After preincubation for $20 \mathrm{~min}$ at $37^{\circ} \mathrm{C}, 1.5 \mu \mathrm{l}$ of $\mathrm{S}_{1}$ nuclease (11000 units $\left./ \mathrm{ml}\right)$ was added and digestion was for $30 \mathrm{~min}$ at $37^{\circ} \mathrm{C}$. The reaction was stopped with $0.1 \% \mathrm{SDS}$ and $5 \mathrm{mM}$ EDTA and the reaction mixture was deproteinized with phenol and ethanol-precipitated as outlined above.

\section{(m) Cloning of double-stranded cDNA}

Size fractionation of double-stranded $c D N A$. Part of the double-stranded cDNA $(4.5 \mu \mathrm{g})$ was layered on a linear 5-23\% sucrose gradient in $50 \mathrm{mM}$ Tris - $\mathrm{HCl}(\mathrm{pH} 7.5), 1 \mathrm{mM}$ EDTA, prepared from a step gradient by three cycles of freezing and thawing. Centrifugation was for $4 \mathrm{~h}$ at $54000 \mathrm{rev} . / \mathrm{min}$ in a Beckman SW60 rotor at $4^{\circ} \mathrm{C}$. Fractionated double-stranded cDNA, longer than 900-1000 nucleotides, was pooled and ethanol-precipitated. The position of double-stranded cDNA longer than 900-1000 bp in this gradient was inferred from the position of ${ }^{32}$ P-labelled marker DNAs of known size run in parallel gradients.

Homopolymer tailing. The 3 '-termini of total or fractionated double-stranded cDNA $(150-200 \mathrm{ng})$ were provided with $\mathrm{dC}$ tails in an $8-\mu$ l reaction volume containing $100 \mathrm{mM}$ sodium cacodylate ( $\mathrm{pH} 7.2$ ), $2.5 \mathrm{mM} \mathrm{CoCl}_{2}, 50 \mu \mathrm{g}$ bovine serum albumin per $\mathrm{ml}, 1 \mathrm{mM}$ dCTP and 3-5 units of terminal deoxynucleotidyl transferase (enzyme obtained from Dr. W. Boll, Zürich) per $\mu \mathrm{g}$ of DNA (Bollum, 1968). After incubation $\left(5-7.5 \mathrm{~min}\right.$ at $27^{\circ} \mathrm{C}$ ) the mixture was diluted to $800 \mu \mathrm{l}$ with TNE and used immediately for annealing with PstI-cleaved, $\mathrm{dG}$-elongated pBR322 vector (see below) or stored frozen at $-20^{\circ} \mathrm{C}$. Plasmid pBR322 (10 $\mu \mathrm{g}$ ) was successively digested with endonuclease PstI, extracted with phenol and ether and precipitated with ethanol. The linearized plasmid was elongated with dGMP in $100 \mathrm{mM}$ sodium cacodylate $(\mathrm{pH} 7.2), 5 \mathrm{mM}$ $\mathrm{MgCl}_{2}, 20 \mathrm{mM} \mathrm{NaH}{ }_{2} \mathrm{PO}_{4}, 50 \mu \mathrm{g}$ bovine serum albumin per $\mathrm{ml}, 1 \mathrm{mM} \mathrm{dGTP}$ and 3-5 units of terminal deoxynucleotidyl transferase per $\mu$ g of DNA (Burrell et al., 1979). After incubation for $20 \mathrm{~min}$ at $37^{\circ} \mathrm{C}$, EDTA was added to $10 \mathrm{mM}$, the reaction mixture was extracted with phenol followed by ether and dialysed for 2 days against TNE buffer.

Annealing reaction. A mixture of dC-elongated double-stranded cDNA (6-10 ng) and dG-tailed linearized pBR322 (12-25 ng) in $50 \mu \mathrm{l}$ TNE buffer was allowed to anneal in four successive 1 -h periods at $65,46,37$ and $20^{\circ} \mathrm{C}$ (Clarke and Carbon, 1975; Van den Berg et al., 1978); then $20 \mu \mathrm{l}$ of $100 \mathrm{mM}$ each of Tris $\cdot \mathrm{HCl}(\mathrm{pH} 7.6), \mathrm{MgCl}_{2}$ and $\mathrm{CaCl}_{2}$ and $50 \mu \mathrm{l}$ of TNE were added and the solution was put on ice until used for transformation of $E$. coli.

Transformation. One colony of $E$. coli $\chi 1776$ was grown in $50 \mathrm{ml}$ tryptone medium (Weissmann and Boll, 1976), supplemented with diaminopimelic acid 
$(100 \mu \mathrm{g} / \mathrm{ml})$ and nalidixic acid $(10 \mu \mathrm{g} / \mathrm{ml})$ at $37^{\circ} \mathrm{C}$ until $A_{650 \mathrm{~nm}}$ was $0.6-0.7$. Calcium-treated cells were prepared as described elsewhere (Van den Berg et al., 1978). The annealed DNA solution $(120 \mu \mathrm{l})$ was mixed with $100 \mu \mathrm{l} \mathrm{Ca}{ }^{2+}$ cells (kept overnight at $0^{\circ} \mathrm{C}$ ) and incubated for $20 \mathrm{~min}$ on ice and for $10 \mathrm{~min}$ at $20^{\circ} \mathrm{C}$. With the aid of a plating wheel, cells were spread directly on a Millipore filter (HAWP); this was put on a tryptone medium agar plate, supplemented with diaminopimelic acid $(100 \mu \mathrm{g} / \mathrm{ml})$, nalidixic acid $(10 \mu \mathrm{g} / \mathrm{ml})$ and tetracycline $(10 \mu \mathrm{g} / \mathrm{ml})$. Transformants were grown at $37^{\circ} \mathrm{C}$ until small $(0.2-0.4$ $\mathrm{mm}$ ) colonies had appeared (usually after $24-36 \mathrm{~h}$ ) and filters were replicated. One filter was quickly frozen and stored at $-70^{\circ} \mathrm{C}$. Preparation, replication and freezing of filters were essentially according to the procedure of D. Hanahan and M. Meselson (personal communication).

Colony hybridization. A modification of the method described by D. Hanahan and M. Meselson (personal communication) was used. Filters containing the colonies were transferred to agar plates containing $12.5 \mu \mathrm{g}$ chloramphenicol per $\mathrm{ml}$ for plasmid amplification; the filters were then incubated in $0.5 \mathrm{M} \mathrm{NaOH}$ to lyse the bacteria, neutralized with $1 \mathrm{M}$ Tris $\cdot \mathrm{HCl}(\mathrm{pH} 7.4)$ and transferred to $1.5 \mathrm{M} \mathrm{NaCl}, 0.5 \mathrm{M}$ Tris $\cdot \mathrm{HCl}(\mathrm{pH} \mathrm{7.4)}$ ). Before drying, filters were pressed between filter paper to remove most of the cell debris and washed in $50 \mathrm{mM}$ $\mathrm{NaCl}$. Dried filters were baked in the oven at $65^{\circ} \mathrm{C}$ for $2-4 \mathrm{~h}$. Before hybridization, filters were washed three times for $1 \mathrm{~h}$ in an excess volume of $4 \times \mathrm{SET}$, $0.2 \%$ SDS with gentle stirring at room temperature. Prehybridization was in the same medium supplemented with $4 \times$ "Denhardt" medium (Denhardt, 1966) for $1 \mathrm{~h}$ at $65^{\circ} \mathrm{C}$ and continued for $2 \mathrm{~h}$ in the presence of $10 \mu \mathrm{g}$ poly(A) per $\mathrm{ml}, 25 \mu \mathrm{g}$ rat-liver carrier RNA per $\mathrm{ml}$ and $50 \mu \mathrm{g}$ alkali-denatured calfthymus DNA per ml. The hybridization solution, pre-equilibrated at $65^{\circ} \mathrm{C}$, contained in addition ${ }^{32} \mathrm{P}$-labelled, heat-denatured cDNA prepared from poly $(\mathrm{A})^{+}$RNA as described above. Up to 35 nitrocellulose filters were hybridized in one glass petri dish under paraffin oil for 12-36 h; per filter ( $7.5 \mathrm{~cm}$ diameter) about $1 \mathrm{ml}$ of hybridization solution was used, containing $0.5-3 \cdot 10^{6}{ }^{32} \mathrm{P} \mathrm{cpm}$ of probe. Filters were washed individually in $2.5 \times$ SET, $0.2 \%$ SDS (three times for $1 \mathrm{~h}$ at $65^{\circ} \mathrm{C}$ ), followed by $3 \mathrm{mM}$ Tris $\cdot \mathrm{HCl}$ base (twice at room temperature). Autoradiographic exposure ( $2-7$ days) was as described above.

\section{(n) Isolation of plasmid DNA}

Colonies were picked from the master filter and grown in tryptone medium containing diaminopimelic acid, nalidixic acid and tetracycline as above. Since clone identification on the filters was unambiguous, recloning was omitted. Chloramphenicol amplification and purification of plasmid DNA was as described elsewhere (Wilkie et al., 1979). All recombinant DNA experiments were done under P3-EK2 containment conditions.

(o) Hybridization selection of $m R N A$

The procedure used is that of Alwine et al. (1977) as modified by $O$. 
Meyuhas and R.P. Perry (unpublished). Recombinant plasmid DNA was covalently attached to DBM paper as follows: $3 \mu \mathrm{g}$ of hybrid plasmid DNA was digested with endonuclease $P$ st $\mathrm{I}$, treated with $20 \mu \mathrm{g}$ pronase per $\mathrm{ml}$ and $0.1 \%$ SDS for $30 \mathrm{~min}$ at $37^{\circ} \mathrm{C}$, extracted with phenol and ether and precipitated with ethanol. The heat-denatured DNA was incubated overnight at $0^{\circ} \mathrm{C}$ with $1 \mathrm{~cm}^{2}$ activated DBM paper (Alwine et al., 1977; Van Ommen et al., 1979 ) in $200 \mu$ l of $25 \mathrm{mM}$ potassium phosphate ( $\mathrm{pH}$ 6.5). Filters were washed three times for $5 \mathrm{~min}$ at room temperature with $50 \mathrm{mM}$ potassium phosphate (pH 6.5 ), $1 \%$ glycine and three times with $99 \%$ recrystallized formamide. A further incubation with $99 \%$ formamide for $2 \mathrm{~min}$ at $68^{\circ} \mathrm{C}$ was followed by three washes in $50 \mathrm{mM}$ potassium phosphate buffer $(\mathrm{pH} \mathrm{6.5})$ at $20^{\circ} \mathrm{C}$. The filters were incubated for $3 \mathrm{~h}$ at $38^{\circ} \mathrm{C}$ in pre-hybridization medium $\mathrm{A}$, supplemented with $1 \%$ glycine, using $330 \mu \mathrm{l}$ per filter. Medium A contains $50 \%$ formamide, $5 \times$ SSC, $2 \times$ "Denhardt" solution without bovine serum albumin, $0.1 \%$ SDS, $25 \mu \mathrm{g}$ poly(A), $25 \mu \mathrm{g}$ yeast RNA and $100 \mu \mathrm{g}$ calf-liver tRNA per $\mathrm{ml}$. The tRNA had been extracted six times with phenol and precipitated with ethanol.

After this pre-hybridization the filters were washed twice in medium $\mathrm{A}$ and then hybridized for $16 \mathrm{~h}$ at $38^{\circ} \mathrm{C}$ with $5-8 \mu \mathrm{g}$ poly $(\mathrm{A})^{+} \mathrm{RNA}$ in medium A under paraffin oil. The RNA was added as follows: one wet DNA filter was put in a sterile petri dish, $33 \mu \mathrm{l}$ of the RNA solution was pipetted on this filter and a second DNA filter was put on top. The sandwich was covered with sterile paraffin oil. After the hybridization the filters were successively washed in medium A ( 2 times), in a solution containing $1 \times \mathrm{SSC}, 0.2 \% \mathrm{SDS}, 1 \mathrm{mM}$ EDTA ( 3 times, 10 min at $20^{\circ} \mathrm{C}$ each), medium A $\left(2 \mathrm{~h}\right.$ at $38^{\circ} \mathrm{C}$ ) and in $50 \%$ for mamide, $5 \times \mathrm{SSC}, 0.1 \% \mathrm{SDS}$ ( 3 times, $10 \mathrm{~min}$ at $20^{\circ} \mathrm{C}$ ). Hybridized RNA was eluted by heating for $1 \mathrm{~min}$ at $100^{\circ} \mathrm{C}$ in $200 \mu 110 \mathrm{mM}$ Tris $\cdot \mathrm{HCl}(\mathrm{pH} 7.4$ ), $1 \mathrm{mM}$ EDTA and $0.1 \%$ SDS. The elution step was repeated once, the eluates were combined and the RNA was precipitated with ethanol after addition of $2 \mu \mathrm{g}$ calf-liver tRNA (purified as above). The washed pellet was vacuum dried and used directly for in vitro translation as described above.

\section{RESULTS}

In vitro translation of poly $(A)^{+} R N A$ containing the $m R N A$ for VSG

Poly $(\mathrm{A})^{+}$RNA was isolated from the four $T$. bruce $i$ variants and translated in a reticulocyte lysate. Lanes c-f of Fig. 1 show an autoradiogram of a SDS gel of the total translation products, lanes $\mathrm{g}-\mathrm{j}$ the gel of the corresponding immunoprecipitates, obtained by incubating each labelled product with antiserum directed against the homologous VSG. In each case the immunoprecipitate contains one major protein band with a mobility in the $50^{--65 \mathrm{kd}}$ region. Three lines of evidence indicate that these major bands are pre-VSGs synthesized in vitro: (1) the molecular weights are close to those of the homologous mature VSGs (Fig. 1, lanes g-j; Table I). We return to the minor differences in mobility between mature VSG and pre-VSG in the DISCUSSION; 


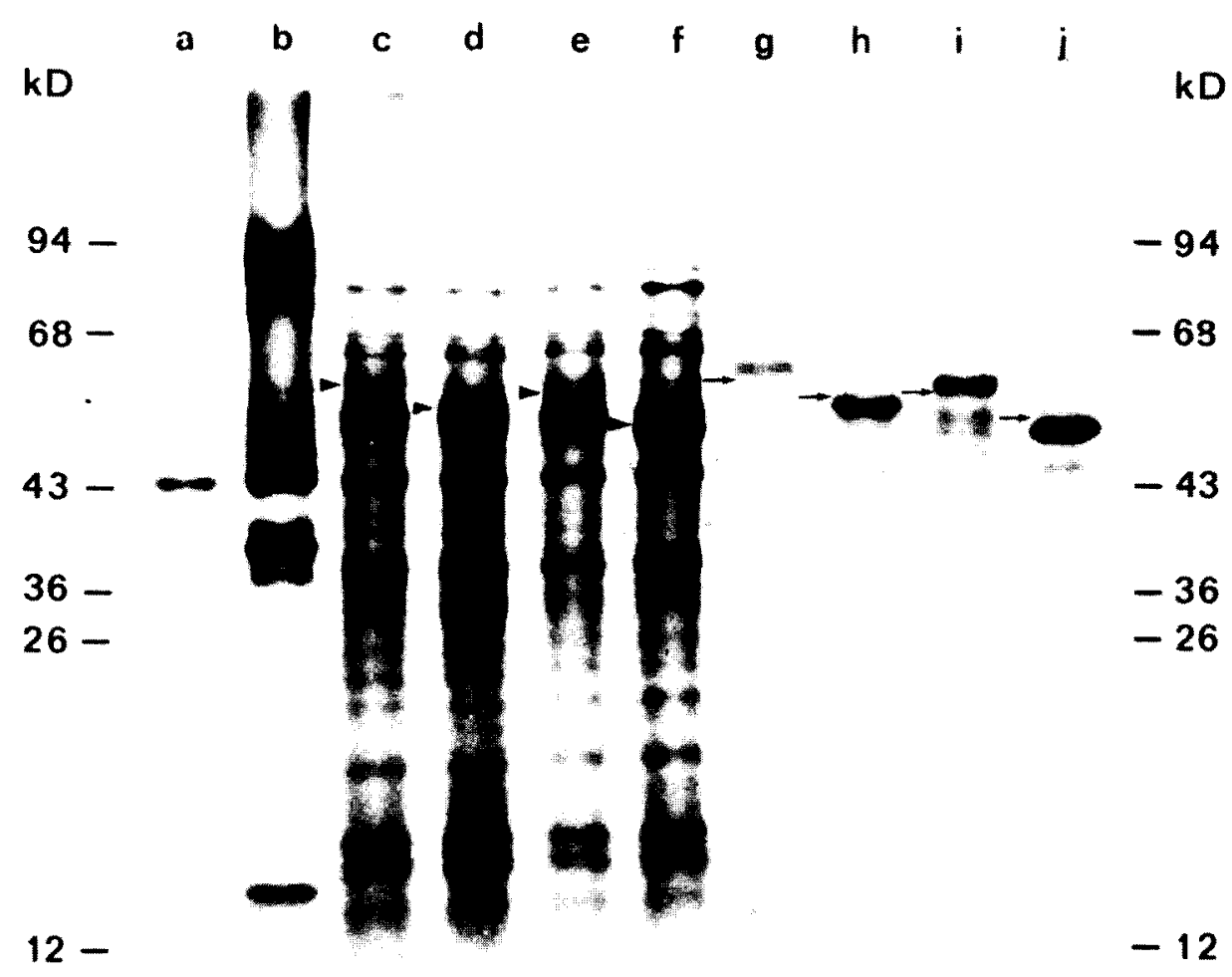

Fig. 1. In vitro translation products of poly $(A)^{+}$RNA from different $T$. bruce $i$ variants. The poly $(\mathrm{A})^{+} \mathrm{RNA}$ was translated in a reticulocyte lysate system and the $\left[{ }^{35} \mathrm{~S}\right]$ methioninelabelled products were analysed on a $15 \%$ SDS polyacrylamide gel. The autoradiogram of the gel is shown. Lane a: endogenous activity; b: stimulated with CPMV mRNA (middle component, gift from Dr. R.W. Goldbach, Landbouwhogeschool, Wageningen); c-f: total protein products synthesized after addition of poly (A) $)^{+}$RNA of variants 117 (c), 118 (d), 121 (e) and 221 (f) (the arrowheads point at the main differences in the protein patterns); $\mathrm{g}-\mathrm{j}$ : immunoprecipitation products of $\mathrm{c}(\mathrm{g}), \mathrm{d}(\mathrm{h})$, e (i) and $f(j)$ with antisera against the homologous VSG of each variant (the arrows indicate the position of the unlabelled homologous VSG run in the same slot). See METHODS for further details. $k D$, kilodaltons

(2) a major band in the gel at this position is only found after immunoprecipitation with homologous antiserum and not with heterologous antiserum (Fig. $2 \mathrm{~A}$ ) or non-immune serum (Fig. 2B, lane $\mathrm{k}$ ); (3) specific precipitation is prevented when the immunoprecipitation is done in the presence of excess unlabelled homologous VSG but not when bovine serum albumin or a nonhomologous VSG is added in excess (Fig. 2B).

In addition to the major bands a few minor bands are also visible in the autoradiograms of the immunoprecipitates. Some of these also show up in 


\section{TABLE I}

A COMPARISON OF THE SIZE OF THE CLONED VSG-SPECIFIC cDNAS WITH THE SIZE OF THE HOMOLOGOUS mRNA, pre-VSG AND VSG

The apparent molecular weights of the pre-VSGs and VSGs were calculated from their mobilities in SDS gels relative to marker proteins (see Fig. 1). The size of the longest cDNA inserts in the recombinant plasmids was calculated from the gel in Fig. 8 , using the data for the seven plasmids that were proven to contain VSG-specific inserts. The numbers in parentheses give the largest cDNA insert in the clone collection shown to have sequence homology with the VSG-specific clones identified in Fig. 7 (see text). The apparent size of the mRNAs was determined from unpublished experiments in which glyoxaltreated poly $(\mathrm{A})^{+}$RNA was size-fractionated by gel electrophoresis, transferred to DBM paper and hybridized with the VSG-specific cDNA plasmids given in the last column.

\begin{tabular}{|c|c|c|c|c|}
\hline \multirow[t]{2}{*}{ Variant } & \multicolumn{2}{|c|}{ Apparent mol. weight of VSG } & \multicolumn{2}{|c|}{ Apparent size of VSG genes } \\
\hline & Precursor & Mature & $\begin{array}{l}\text { mRNA } \\
\text { (nucl.) }\end{array}$ & $\begin{array}{l}\text { cloned cDNA } \\
\text { (bp) }\end{array}$ \\
\hline 117 & 62000 & 61000 & 2250 & $820(1600)$ \\
\hline 118 & 57000 & 58000 & 2050 & $1500(1600)$ \\
\hline 121 & 59500 & 58500 & 2150 & $800(1150)$ \\
\hline 221 & 52000 & 53000 & 1950 & 1200 \\
\hline
\end{tabular}

controls, others are specific for the antiserum used and may represent preVSG fragments.

We conclude from these results that the poly $(\mathrm{A})^{+} \mathrm{RNA}$ preparations that we have isolated from these four T. brucei variants contain full-length mRNA for VSG and should be suitable starting material for the construction of cDNA complementary to VSG mRNA. We also note that the total translation products of the four poly $(\mathrm{A})^{+}$RNA preparations yield a similar series of bands on an SDS gel (Fig. 1, lanes c-f); the only major difference is in the region of the gel where the pre-VSGs migrate (arrow heads). This result indicates that the only major difference in these four RNA preparations is the difference in pre-VSG mRNA.

\section{Construction and cloning of hybrid plasmids containing DNA complementary} to $\operatorname{poly}(A)^{+}$RNA

For the synthesis of duplex cDNA and the construction and cloning of hybrid plasmids we have used the published procedure outlined in Fig. 3 (Villa-Komaroff et al., 1978). The synthesis of the first DNA strand with reverse transcriptase was followed by including $\left[\alpha-{ }^{32} \mathrm{P}\right] \mathrm{dATP}$ in the reaction mixture. The size distribution of the product synthesized was determined by alkaline agarose gel electrophoresis as shown in Fig. 4A. The modal size of the product is 900 nucleotides, but there is cDNA present up to 2500 nucleotides long. The significance of the separate DNA band visible at around 1900 nucleotides in the background of heterogeneous DNA is not known. The 
A
kD
a
c d
e
g h
KD
94 -
$68-$
$-68$
$43-$
$-43$
36 -
$-36$
26 -
$-26$

$12-$

$-12$

$\begin{array}{rllllllll}\text { poly (A) RNA } & 117 & 117 & 118 & 118 & 121 & 121 & 221 & 221 \\ \text { SG antiserum } & 117 & 118 & 118 & 117 & 121 & 221 & 221 & 121\end{array}$

B

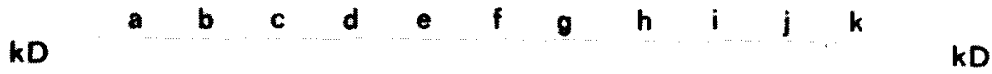

94 -

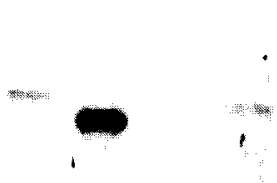

$43-$

$36-$

26 -

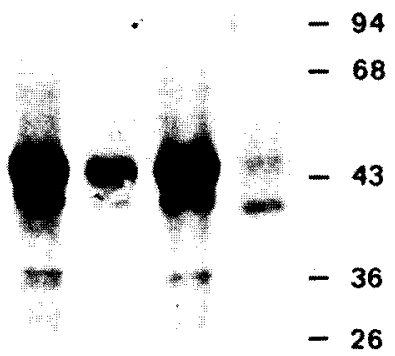

$12-$

$-12$

$\begin{array}{llllllllllll}\text { poly }(A)^{+} \text {RNA } & 117 & 117 & 117 & 118 & 118 & 121 & 121 & 221 & 221 & 221 & 221\end{array}$

VSG excess - $117118-118-121-221^{a} \mathrm{BSA}-\mathrm{b}$ 


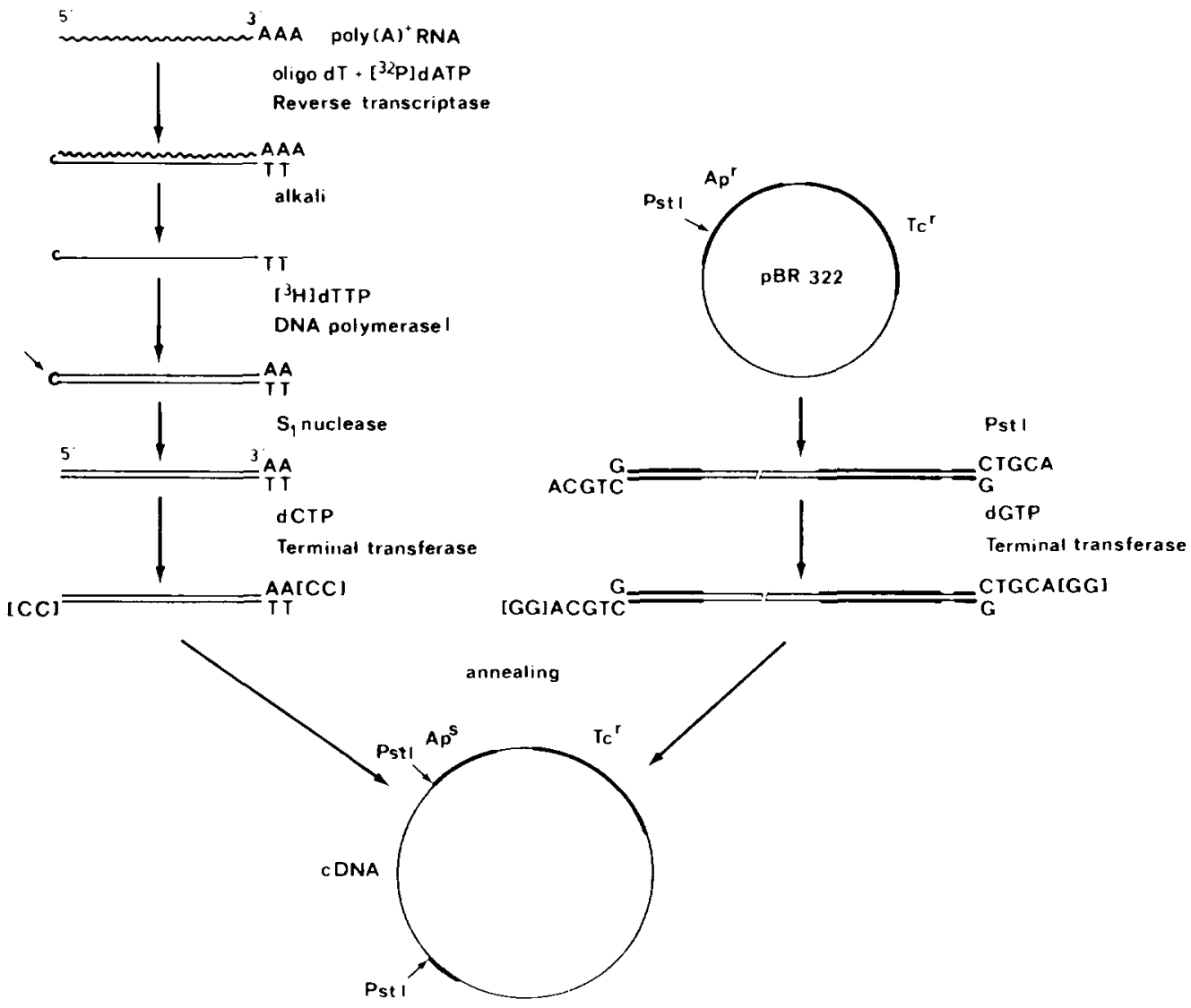

Fig. 3. General scheme of the synthesis of double-stranded DNA complementary to poly $(\mathrm{A})^{+}$ RNA from trypanosomes and its subsequent ligation to plasmid pBR322.

Fig. 2. Specificity of the immunoprecipitation of in vitro translation products. (A) Trypanosome-specific translation products, made as in Fig. 1, were immunoprecipitated either with homologous or heterologous anti-VSG antiserum and the immunoprecipitate was analysed on a gel and autoradiographed as in Fig. 1. The poly $(\mathrm{A})^{+}$RNA used to programme the reticulocyte lysate and the anti-VSG antiserum used to immunoprecipitate the labelled protein products are indicated below each lane. (B) Immunoprecipitation of trypanosomespecific translation products in the presence of excess homologous or heterologous VSGs. All immunoprecipitations were done with antiserum against the homologous VSG except in lane $\mathbf{k}$ for which non-immune serum was used. The poly $(\mathrm{A})^{+}$RNA used to programme the reticulocy te lysate and components (in all cases $25 \mu \mathrm{g}$ ) used to compete in the immuno precipitation are indicated below each lane.

ancomplete competition.

b Non-immune serum used for immunoprecipitation. 
globin mRNA control (Fig. 4, lane c) shows that full-length globin cDNA is made under our reaction conditions.

Synthesis of the second strand was monitored with $\left[{ }^{3} \mathrm{H}\right] \mathrm{dTTP}$. The average size of the duplex cDNA product after treatment with $\mathrm{S}_{1}$ nuclease was about 700 nucleotides (Fig. 4B), i.e. about 200 nucleotides less than the product of the first strand synthesis. The yield at this stage was about 6-7.5 $\mu \mathrm{g}$ duplex cDNA per $45 \mu \mathrm{g}$ of poly $(\mathrm{A})^{+} \mathrm{RNA}$, depending on the trypanosome variant.

Part of the duplex cDNA was size-fractionated on neutral sucrose gradients and material sedimenting faster than the 900-1000 bp markers run in parallel gradients was pooled and used for $\mathrm{dC}$ tailing (see Fig. 3). After annealing the dC-tailed cDNA with dG-tailed PstI-cleaved pBR322, the recombinant plasmid was brought into $E$. coli $\chi 1776$ and a total of $2000-4000$ tetracycline-resist-

A
b.
a b c d e f g h i

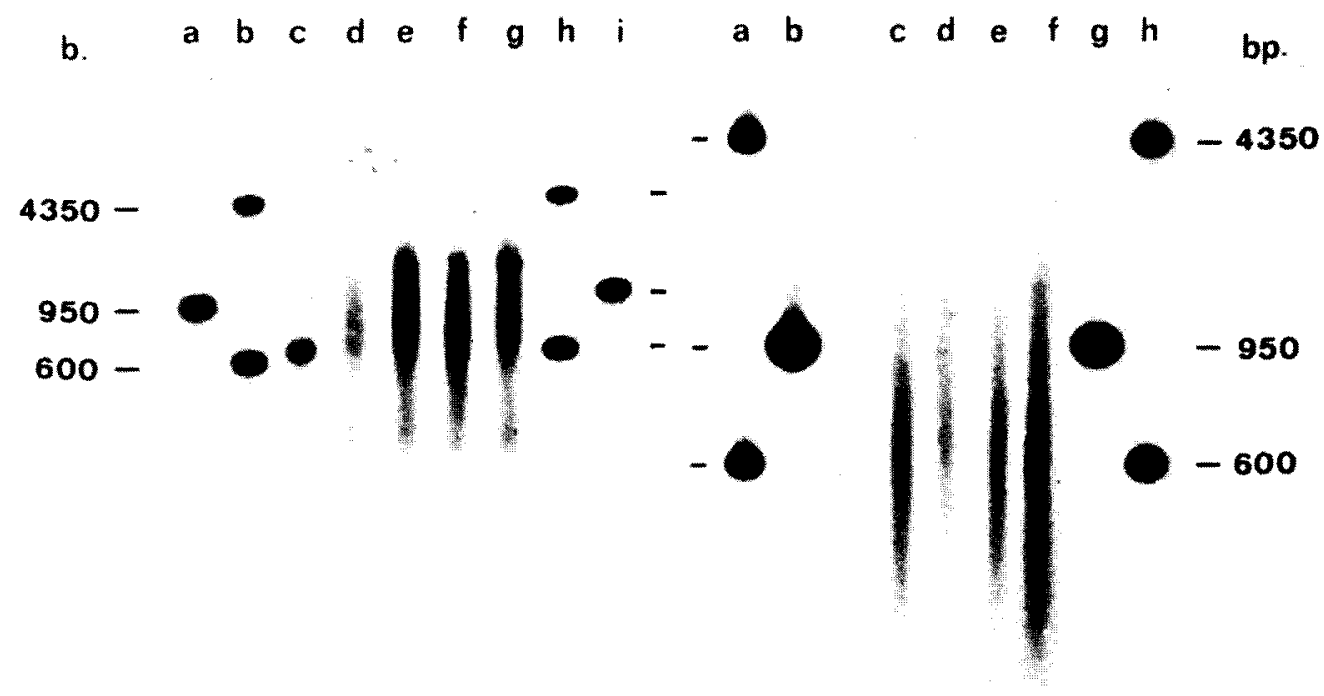

B

Fig. 4. Sizing of the cDNAs made in vitro with poly $(A)^{+}$RNA from $T$. brucei as template. (A) The single-stranded ${ }^{32} \mathrm{P}$-labelled cDNA made in the synthesis of the first strand was electrophoresed in a $1.5 \%$ agarose gel under alkaline conditions (see METHODS). The autoradiogram of the dried gel is shown. Lanes $a, b, h$ and $i$ contain DNA markers endlabelled with polynucleotide kinase and with the molecular weights indicated; $c$ : control showing single-stranded cDNA of globin mRNA (approx. 700 nucleotides long); $d-g$ : single-stranded $\mathrm{cDNA}$ of poly $(\mathrm{A})^{+}$RNA from variant 117 (d), 118 (e), 121 (f) and 221 (g). (B) Double-stranded ${ }^{32} \mathrm{P}$-labelled cDNA obtained after synthesis of the second strand and treatment with $S_{1}$ nuclease was run on a $2.0 \%$ neutral agarose gel. Lanes $a, b, g$ and $h$ contain molecular weight markers as in $\mathrm{A} ; \mathrm{c}-\mathrm{f}$ : double-stranded cDNA of poly $(\mathrm{A})^{+} \mathrm{RNA}$ from variant 117 (c), 118 (d), 121 (e) and 221 (f). 
ant transformants was selected for each variant. Transformation efficiency varied between 10000 and 30000 colonies per $\mu \mathrm{g}$ of annealed plasmid DNA. Control transformation with dG-elongated, PstI-cleaved pBR322 alone gave less than $5 \%$ of the number of transformants obtained in experiments with the recombinant DNA plasmid.

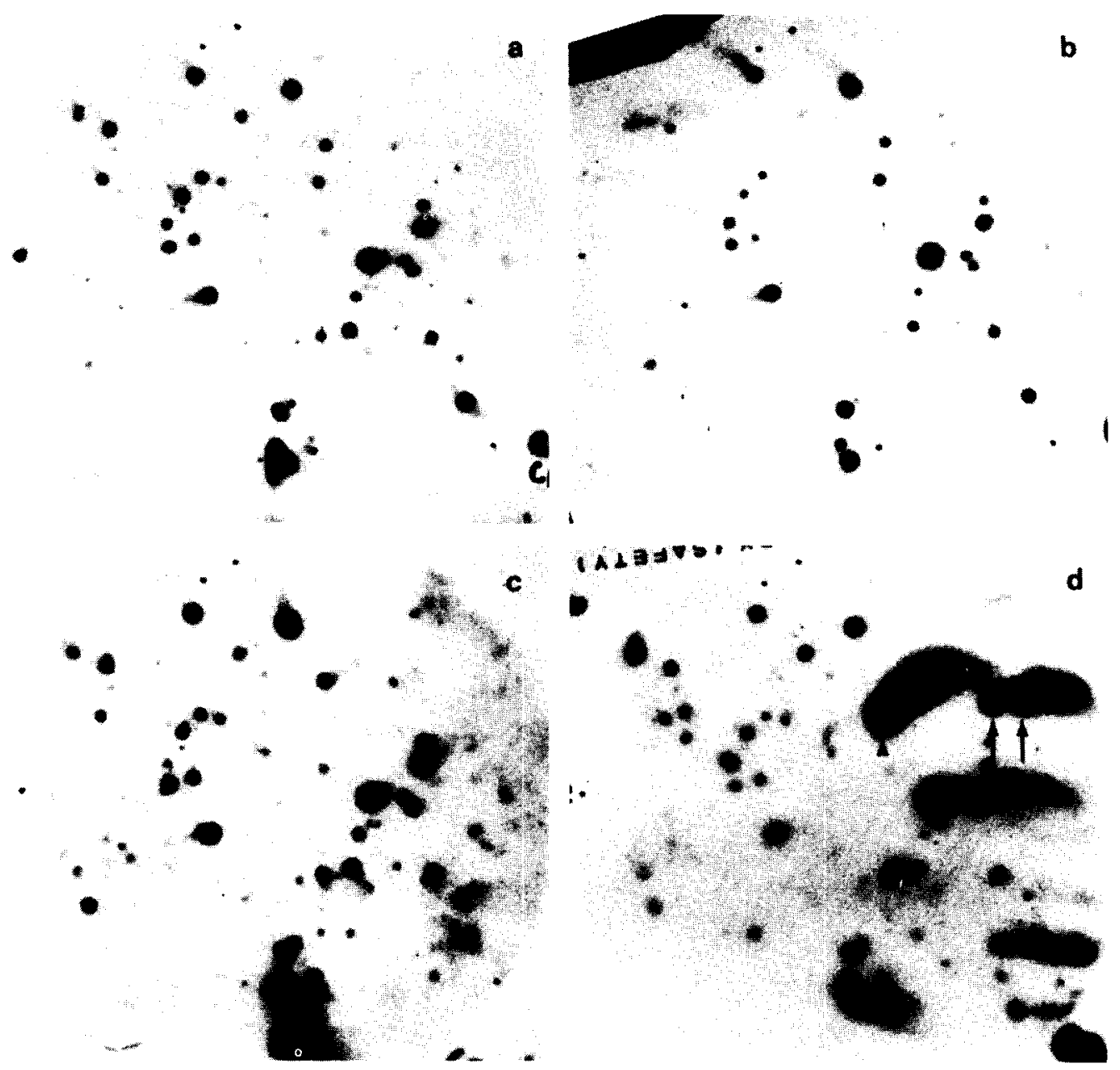

Fig. 5. Differential colony hybridization. Four replica filters with colonies transformed with $\mathrm{cDNA}$ of variant 118 were hybridized with $\mathrm{cDNA}$ probes complementary to four different $\operatorname{poly}(\mathrm{A})^{+}$RNA preparations. Filters a-c: Heterologous hybridizations using ${ }^{32}$ P-labelled cDNA of variants 117 (a), 121 (b) and 221 (c); d: hybridized with ${ }^{32}$ P-labelled cDNA of variant 118 (homologous hybridization). The arrows point at clear examples of colonies visible only in the homologous hybridization. The arrow head shows a strongly hybridizing colony that might be identical to a weakly hybridizing spot in filters a and $\mathrm{b}$. 
Identification of hybrid plasmids containing DNA complementary to variable antigen $m R N A$ by differential colony hybridization

The four trypanosome variants used for the isolation of poly $(\mathrm{A})^{+} \mathrm{RNA}$ were originally derived from one $T$. brucei cell. The variants were grown under identical conditions and the RNA preparations from different variants were made in the same way. Presumably, any differences in the RNAs from different variants should, therefore, be due to the difference in variable antigen mRNAs (see Fig. 1, lanes $\mathrm{c}-\mathrm{f}$ ). Clones containing DNA complementary to these variable antigen mRNAs should, therefore, only (or predominantly) hybridize to homologous poly $(\mathrm{A})^{+} \mathrm{RNA}$ and not to RNA from the other three clones. To find the desired clones, $E$. coli transformants were grown on nitrocellulose filters and replicated on four other filters. After chloramphenicol amplification the cells were lysed with alkali and the single-stranded DNA was fixed onto the filter by a modification of the procedure of Grunstein and Hogness (1975). The filters were then hybridized with variant-specific labelled cDNA probes, each of the four probes with a separate replica filter. The probe was cDNA complementary to poly $(A)^{+}$RNA in these experiments rather than the poly $(\mathrm{A})^{+} \mathrm{RNA}$ itself because the oligo(dT)-primed synthesis of cDNA selects against contaminating rRNA and results in higher specific activities than obtained with kinase-labelled RNA.

The results of an experiment with colonies containing hybrid plasmids of variant 118 cDNA are shown in Fig. 5. The colonies hybridizing with heterologous cDNAs on filters $\mathrm{a}, \mathrm{b}$ and $\mathrm{c}$ are similar except for some quantitative differences. We attribute these to minor differences in the size of replicated colonies. The hybridization with the homologous cDNA of variant 118 in filter $\mathrm{d}$ shows the same hybridizing colonies as in the heterologous hybridization, but there are 3 to 4 additional, strongly hybridizing spots not present in the autoradiograms of filters $a-c$. Such colonies, specific for one variant, were also observed in all other homologous hybridizations (results

Fig. 6. Characterization of recombinant DNA plasmids from variant-specific bacterial clones by filter hybridization. 37 partly-purified hybrid plasmid DNAs were digested with endonuclease Pst $\mathrm{I}$, electrophoresed in $1.5 \%$ agarose and blotted onto nitrocellulose filters. Two series of filters containing identical digests were hybridized with ${ }^{32} \mathrm{P}$-labelled cDNA made on poly $(\mathrm{A})^{+}$RNA from variant 118 (panel A) or 221 (panel B). Lanes $1-8$ contain plasmids from colonies hybridizing mainly with cDNA made on poly $(A)^{+}$ RNA from variant 117 (cf. Fig. 5), lanes 9-16 from variant 118; lanes 17-25 from variant 121 ; lanes $26-37$ from variant 221 . Lane 38 in panel $B$ represents the photograph of slot 30 of the ethidium bromide-stained gel; the heterogeneous smear of DNA is caused by $E$. coli chromosomal DNA. Lane 39 represents the autoradiogram of slot 30 after hybridization with alkali-fragmented poly $(\mathrm{A})^{+}$RNA from variant 221 , end-labelled with $\left[\gamma^{32} \mathrm{P}\right]$ ATP. Digestion of the DNAs in slots 9 and 36 by PstI was incomplete and most of the other slots show also partial digestion products (e.g. just above the position of linearized pBR322) but to a lesser degree. Some hybrid plasmids have lost one of the Pst I recognition sites at the edges of the insert (e.g. slot 11). In panel $B$ there is a weak and variable hybridization with pBR322 that we attribute to a slight contamination of the probe with pBR322 sequences. Exposure of the hybridized filter was for $12 \mathrm{~h}$ at room temperature without intensifying screen. 


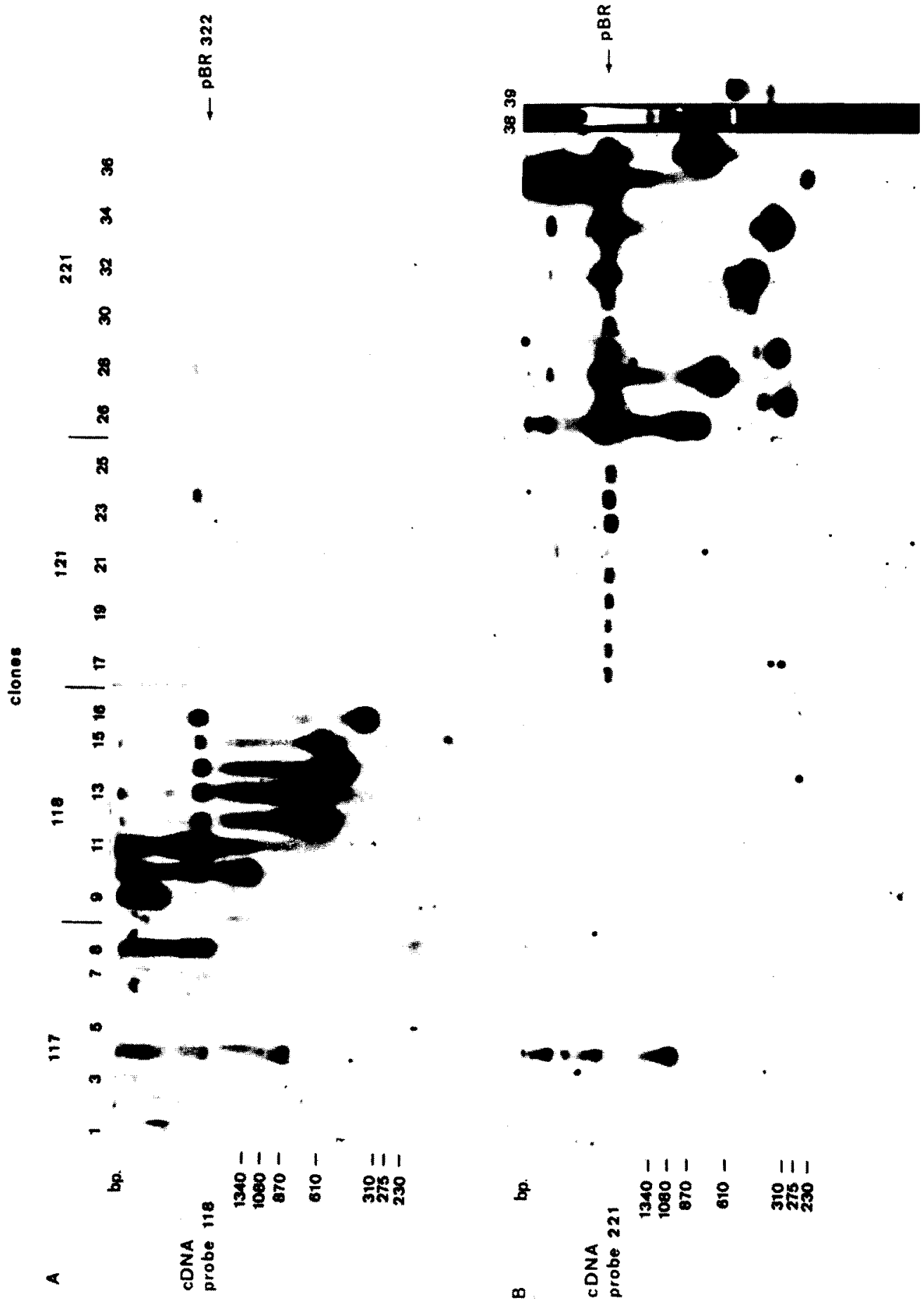


not shown); their frequency varied between 7 and $10 \%$ of all hybridizing colonies.

\section{Analysis of selected hybrid plasmids by hybridization with (cDNA made on) $\operatorname{poly}(A)^{+} R N A$}

Hybridization with DNA from lysed colonies only provides semi-quantitative results, because the colony size may vary. The clones selected were, therefore, further characterized by hybridizing cDNA made on poly $(\mathrm{A})^{+}$ RNA to the isolated plasmid DNAs. The partly purified hybrid plasmids were digested with endonuclease PstI, which cleaves at the borders of the inserted sequence (Bolivar et al., 1977; Villa-Komaroff et al., 1978). All recombinants contained a DNA insert (data not shown). PstI-cleaved plasmids were electrophoresed on agarose gels and the alkali-denatured DNA transferred to nitrocellulose filters. Four identical blots were hybridized separately with hot cDNA probes of all four poly $(\mathrm{A})^{+} \mathrm{RNA}$ preparations. Fig. $6 \mathrm{~A}$ shows nitrocellulose filters containing 37 PstI-digested hybrid plasmids, hybridized with a 118 probe (panel A) and a 221 probe (panel B). Although many of the PstI digests of these crude plasmid preparations were incomplete, the results of the hybridization experiments are clear. Extensive hybridization is found only with homologous inserts with two exceptions:

(1) Some of the inserts do not show hybridization with their homologous cDNA probes (Fig. $6 \mathrm{~B}$, lanes 30,33 and 35 ). This may be due to inserts that do not start at the 3 '-end of the mRNA and that are consequently not recognized by the short cDNA probe used in this experiment. This is confirmed by hybridization experiments with labelled poly $(\mathrm{A})^{+} \mathrm{RNA}$, which show that one such insert does contain sequences complementary to homologous total poly (A) ${ }^{+}$RNA (Fig. 6B, lane 39).

(2) A few recombinant plasmids hybridize extensively to heterologous cDNA (Fig. 6). For instance, clone 117-4 is recognized by cDNA from both variants 118 and 221 and also by a 121 probe (not shown). This is not surprising

Fig. 7. Identification of recombinant plasmids containing VSG mRNA sequences. Recombinant plasmids were cleaved with Pst I, denatured and covalently attached to DBM paper. The DNA filters were hybridized to homologous poly $(A)^{+}$RNA, washed and the retained RNA was eluted and translated in a reticulocyte lysate. The figure shows the autoradiogram of the $\left[{ }^{35} \mathrm{~S}\right]$ methionine-labelled protein products after electrophoresis through an SDS polyacrylamide gel. Underneath each lane we have indicated which RNA was used to programme the translation system, whether the translation products were immunoprecipitated with homologous antiserum and whether the RNA was hybridized to filter-bound DNA before the gel analysis. Lane a shows the endogenous activity of the reticulocyte lysate; the prominent band at $43 \mathrm{kd}$ is present in most of the other lanes. The recombinant plasmids used for the hybridization selection are specified. Lanes $d$ and $e:$ plasmid 117-1 (see Fig. 8, lane c); lanes $f$ and g: plasmid 117-2; lanes $h$ and $i$ : pBR322 DNA without insert; lanes $l$ and $\mathrm{m}$ : plasmid 118-2 (see Fig. 6, lane 10 and Fig. 8, lane f); lanes p and q; plasmid 121-3 (see Fig. 8, lane g); lanes $t$ and u: plasmid 221-5 (see Fig. 6, lane 38 and Fig. 8, lane i). $\mathrm{kD}$, kilodaltons. 


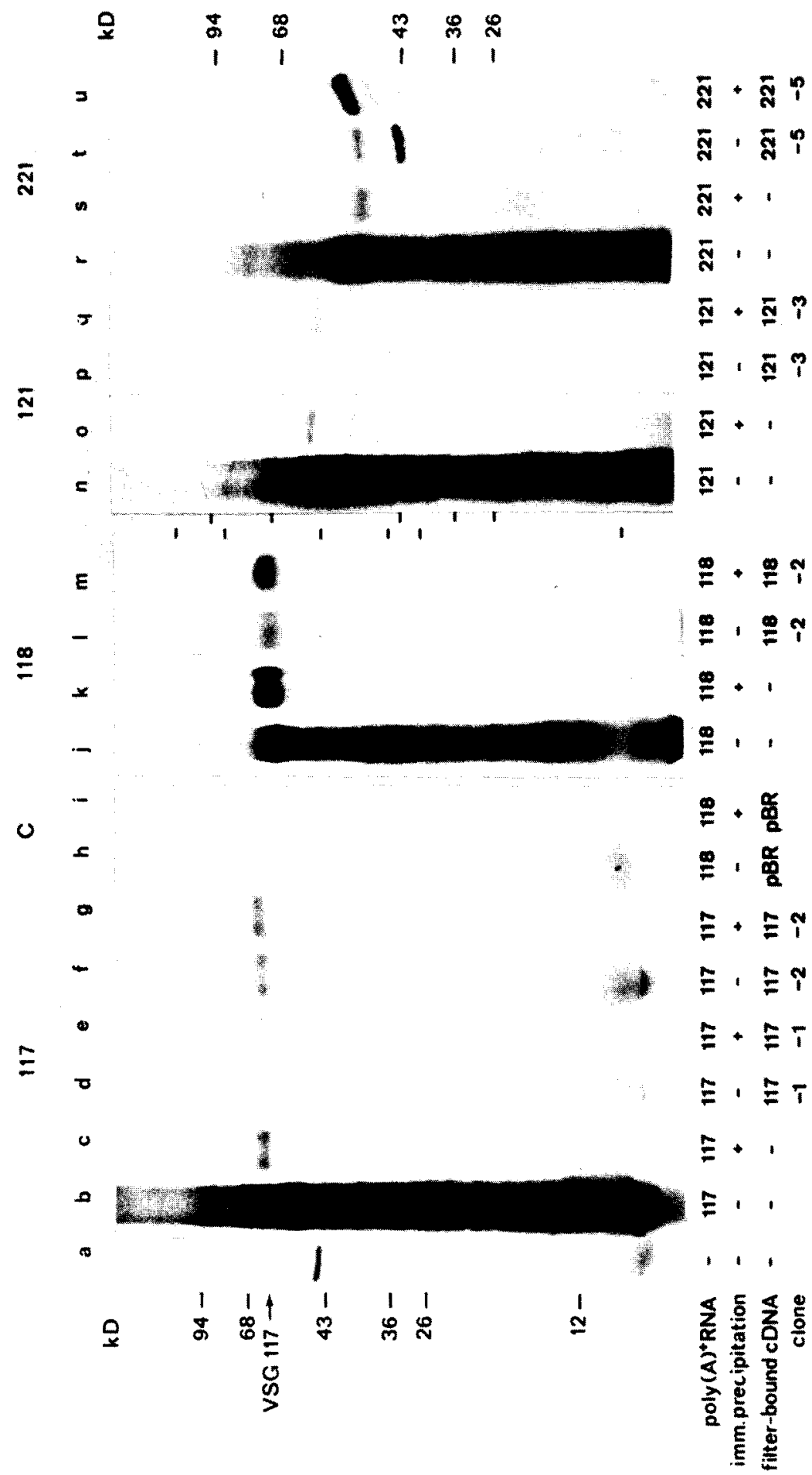


because Fig. 6 includes clones that showed already some cross-hybridization to heterologous RNA in the colony hybridization.

Out of 37 clones, 31 were found to be variant-specific showing that our approach to isolate variant-specific cDNA clones by differential hybridization works in practice.

In vitro translation of $m R N A$ selected by hybridization to recombinant plasmid $D N A$

To prove that the variant-specific plasmids contained DNA complementary to VSG mRNA, denatured plasmid DNA was immobilized on DBM paper and hybridized with homologous poly $(\mathrm{A})^{+} \mathrm{RNA}$. The hybridized RNA was eluted and translated in the reticulocyte lysate. The results with cDNA clones of each variant are given in Fig. 7. Three other hybrid plasmid DNAs gave analogous results, two were negative. Comparison of the protein products of the total poly $(\mathrm{A})^{+} \mathrm{RNA}$ and the corresponding RNA selected by hybridization demonstrates that the mRNA for a protein with the mobility of the VSG protein is highly enriched by the hybridization step. The immunoprecipitations confirm that this mRNA is the homologous VSG mRNA. A control experiment in lanes $h$ and $i$ using pBR322 DNA without insert and poly $(A)^{+}$RNA from variant 118 demonstrates that these results are not due to aspecific sticking of VSG mRNA to filters or to other artefacts in the procedure. We conclude that each hybrid plasmid used in these experiments contains sequences complementary to the VSG mRNA of the corresponding variant.

Preliminary characterization and sequence homology of plasmids containing DNA complementary to different VSG mRNAs

The experiments in Figs. 5 and 6 show that there is no significant homology between the 3 -terminal parts of the VSG mRNAs because the short cDNA probes did not show cross-hybridization. To determine the amount of sequence homology in the total cloned VSG cDNAs of different variants we used alkalifragmented total poly $(\mathrm{A})^{+} \mathrm{RNA}$ labelled in vitro with polynucleotide kinase. Fig. 8 shows the hybridization of the poly $(\mathrm{A})^{+} \mathrm{RNA}$ of each variant hybridized with eight clones, seven of which have been identified as VSG-specific by the procedure shown in Fig. 7, one by the hybridization experiment described below. In all cases only the cDNA of the homologous VSG mRNA shows hybridization.

We hybridize and wash the hybrids in $2 \times \mathrm{SSC}$ at $60^{\circ} \mathrm{C}$. The mole percent $\mathrm{G}+\mathrm{C}$ of the main component in T. brucei nuclear DNA, inferred from its density in $\mathrm{CsCl}$ (Newton and Burnett, 1972), is 47\%. If the base composition of the VSG mRNAs is close to that of the main DNA component, our hybridization conditions are $30^{\circ} \mathrm{C}$ below the $t_{\mathrm{m}}$ of the hybrids. It follows that the sequence homology between the cloned parts of the mRNAs of these four variants cannot be extensive.

Although several of the cloned cDNAs shown in Fig. 8 contain internal PstI sites, the digests of two clones of the same variant do not always have 
(A)

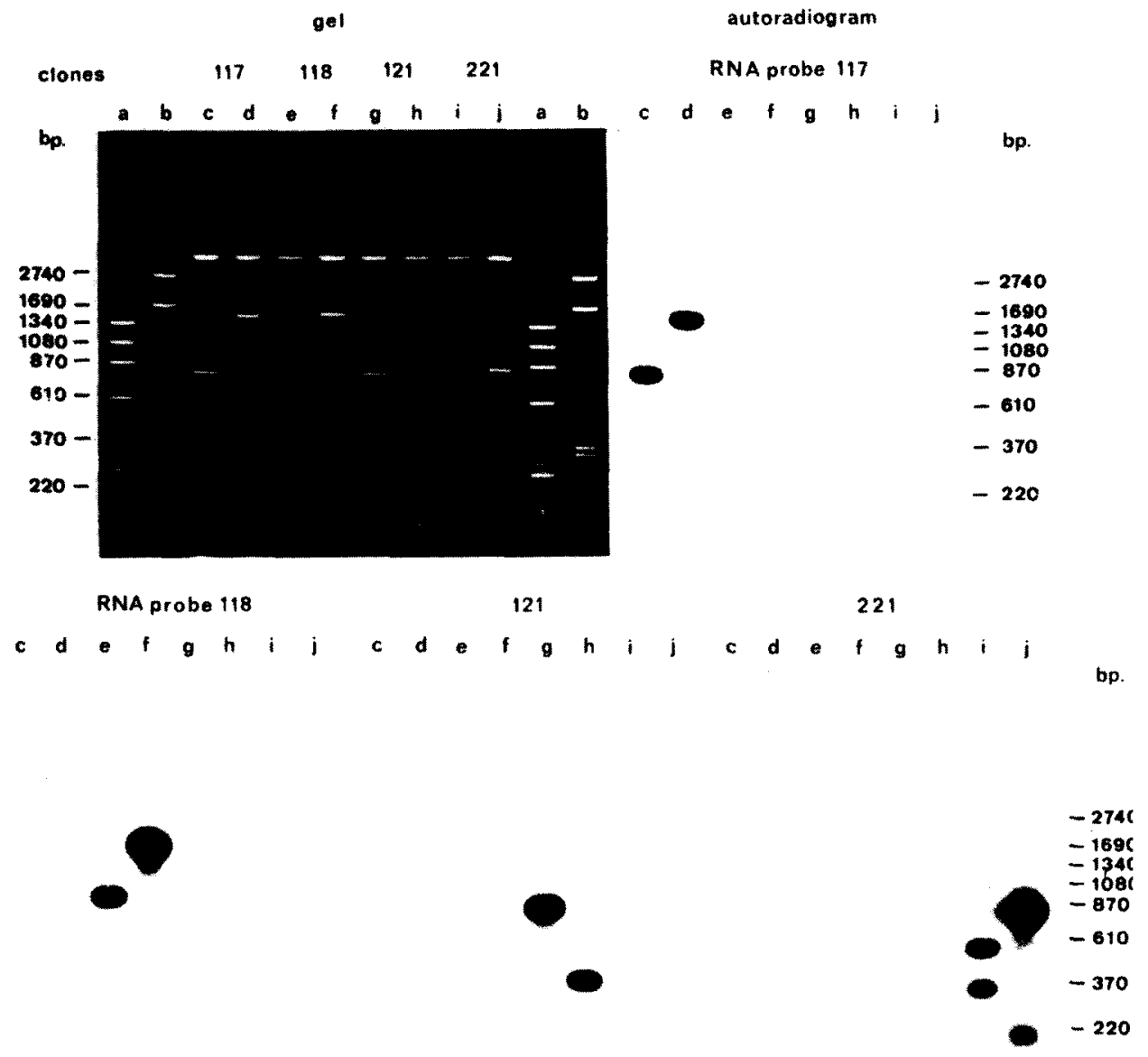

(C)

(D)

$(\mathrm{E})$

Fig. 8. Characterization of purified VSG cDNA plasmids by hybridization with poly $(A)^{+}$ RNA. From the experiment in Fig. 6 eight variant-specific clones were selected, two for each variant. Recombinant plasmids were purified from each clone and digested with Pst $\mathrm{I}$; the digests were then size-fractionated by electrophoresis through a $2 \%$ agarose gel. Panel A shows the fluorescence of the ethidium bromide-stained gel. Lanes $\mathrm{c}$ and $\mathrm{d}$ show plasmids containing $117 \mathrm{cDNA}$ inserts; lanes e and $\mathrm{f}$ : plasmids with $118 \mathrm{cDNA}$ inserts; lanes $\mathrm{g}$ and $\mathrm{h}$ : plasmids with $121 \mathrm{cDNA}$ inserts; lanes $\mathrm{i}$ and $\mathrm{j}$ : plasmids with $221 \mathrm{cDNA}$ inserts. The molecular weight standards in lanes a and $b$ are phage $\phi$ X174 RF DNA digested with endonucleases $M s p I$ (a) and BspI (b), respectively. The band at $4.4 \mathrm{~kb}$ is linearized pBR322; the other fragments in lanes $c-j$ are derived from the inserted cDNA. Four gels identical to the one of panel A were blotted onto nitrocellulose filters and hybridized with alkalifragmented total poly $(\mathrm{A})^{+}$RNA labelled in vitro with polynucleotide kinase. Panels $\mathrm{B}-\mathrm{E}$ show the autoradiograms after hybridization with poly $(\mathrm{A})^{+} \mathrm{RNA}$ of variants 117,118 , 121 and 221 , respectively. The plasmids in lanes $\mathrm{c}-\mathrm{j}$ are from the same clones as the partly purified plasmid preparations shown in Fig. 6, lanes 1, 5, 14, 10, 19, 21, 30 and 37, respectively. The plasmids in lanes $\mathrm{c}$ and $\mathrm{e}-\mathrm{j}$ were shown to hybridize with homologous VSG mRNA in the experiment shown in Fig. 7 and similar experiments. 
the expected fragments in common. An example is shown in lanes $\mathrm{i}$ and $\mathrm{j}$ of Fig. 8. As mentioned above, this is due to the absence of the $3^{\prime}$-end of the mRNA sequences in the clone present in lane i of Fig. 8 (cf. lanes 30, 38, 39 of Fig. 6).

To further analyse which fraction of the clones is VSG-specific, the insert was cut from plasmids identified as VSG-specific in Fig. 7 and these inserts were hybridized to Southern blots containing a series of PstI-digested recombinant plasmids (cf. Fig. 6). Of the 36 clones analysed, 32 were unambiguously VSG-specific (this includes the 8 already identified as such). Two were negative and both of these were not variant-specific; two remain to be sorted out (Bernards, A., Hoeijmakers, J.H.J. and Borst, P., unpublished). These results show that the VSG $\mathrm{mRNA}$ is the major variant-specific mRNA giving rise to cDNA clones in these experiments.

Table I compares for each variant the size of the cloned cDNA with the size of the homologous VSG mRNA and protein product. The size of the cloned cDNA was calculated from the gel in Fig. 8 and similar gels, disregarding the size of the GC tails. Such tails have not been found to exceed $30 \mathrm{bp}$, however, in the recombinant plasmids investigated (Villa-Komaroff et al., 1978; Chang et al., 1978; Gordon et al., 1978). We conclude from Table I that our VSGspecific cDNAs cover at least half of the corresponding mRNAs.

\section{DISCUSSION}

The differential hybridization approach used by us has made it relatively simple to isolate recombinant DNA plasmids containing DNA complementary to specific VSG mRNAs. None of the clones yet examined contains a cDNA insert of the size expected for a full-length copy of VSG mRNA. From RNA blotting experiments of glyoxal-treated, gel-fractionated RNA we infer that the VSG mRNAs are 1950-2250 nucleotides, depending on the variant analysed (see Table I). The largest VSG-specific insert found thus far is only $1600 \mathrm{bp}$. The large variation in the size of the inserts found in the total clone collection suggests that there are no major blocks in the reverse transcription of VSG mRNA or major segments in the cDNA that are systematically deleted out in $E$. coli. Full-length cDNA clones may, therefore, still be present in our clone bank.

Cloned cDNA complementary to the mRNA for one VSG has also been obtained recently by R.O. Williams and co-workers (personal communication), starting from highly purified mRNA. Our approach avoids lengthy mRNA purification steps and lends itself more readily to the isolation of cDNA clones from several variants. In fact, it should be possible to mix poly $(\mathrm{A})^{+} \mathrm{RNA}$ from ten different variants and make one clone bank from which the ten cDNAs are selected by differential hybridization.

Our results are compatible with the conclusion of Williams et al. (1978) that the mRNA for VSG is a major mRNA in bloodstream trypanosomes. In unfractionated cDNA about $2-3 \%$ of the colonies were variant-specific 
(results not shown); in the size-fractionated cDNA this rose to 7-10\%. In the colony hybridization the variant-specific colonies usually hybridized to a much greater extent than most of the other colonies. Although preferential transcription by reverse transcriptase could contribute to this, the simplest interpretation of our results is that the trypanosome makes the large amounts of VSG required (5-10\% of the total cellular protein, see Cross (1979)) by maintaining a high concentration of VSG mRNA.

The main aim of this work was the construction of recombinant DNA clones, but the results obtained also provide information on some of the steps involved in the synthesis of VSGs. The data in Table I show that there is considerable difference in the mobilities in SDS gels of the four VSGs analysed here. The rather low apparent size of VSG 221 has been noted before (Johnson and Cross, 1979), but was tentatively attributed to proteolysis. This now appears unlikely, because the pre-VSG 221 and its mRNA have also lower apparent molecular weights than those of the other VSGs. Moreover, the short $221 \mathrm{VSG}$ has a C-terminal glycopeptide structure similar to that found in the higher molecular weight VSGs (Holder, A.A. and Cross, G.A.M., unpublished). Apparently, VSGs of rather diverse sizes can be used to make a functional surface coat.

The reticulocyte system is not known to glycosylate nascent proteins and, since glycosylated proteins usually run slower in SDS gels than their nonglycosylated counterparts, one would expect the pre-VSGs to migrate ahead of their mature counterparts. In Fig. 1 this was only seen with variants 118 and 221 , whereas the pre-VSGs 117 and 121 migrate even slightly slower than their mature counterparts. It seems possible, therefore, that the preVSG made in the reticulocyte system contain a "signal peptide" involved in the transfer of the nascent protein to the surface. It has recently been demonstrated that VSG is synthesized on membrane-bound polysomes (Lheureux et al., 1979).

The fact that it is possible at all to get VSG-specific cDNA clones, suggests that the $3^{\prime}$-halves of the mRNAs for the four VSGs studied lack substantial sequence homology (disregarding the poly(A) tail). It could be argued, however, that the selection procedure used selects against clones that contain segments of the mRNA that are homologous in the four variants. Inadvertently we might, therefore, have cloned different parts of the mRNA of each variant. That this interpretation is incorrect is shown by the preliminary analysis of the clones. The maximal size of the VSG-specific inserts ranges from $1150 \mathrm{bp} \mathrm{(121)}$ to $1600 \mathrm{bp}(117$ and 118). Since the estimated size of the mRNAs is $1950-2250$ nucleotides (Table I), it is not possible to divide this up in four different segments of $1150-1600 \mathrm{bp}$. Moreover, most inserts hybridize well with reverse transcripts made on homologous poly $(\mathrm{A})^{+} \mathrm{RNA}$; since this cDNA was oligo(dT)-primed and of limited size (see Fig. 6) it should predominantly recognize the 3 '-terminus of the mRNA. These results - taken together - strongly indicate that our clones cover the 3 '-halves of the four mRNAs studied and hence that these share no major sequence 
homology. It follows that functional VSG genes are not made like the genes for immunoglobulin chains in antibody-forming cells (see Dunninck, 1979), by welding one of a large repertoire of genes for the variable $\mathrm{N}$-terminal half onto one or two genes for a constant C-terminal half. The little that is known of the C-terminal amino acid sequence of variants $117,118,121$ and 221 (A.A. Holder and G.A.M. Cross, unpublished) is in agreement with this conclusion.

Using two other variants of $T$. brucei, Williams et al. (1978) have recently analysed whether the mRNA coding for the VSG of one variant was also present in the other. In hybridization experiments with cDNA made on partially purified VSG mRNA, they observed the presence of an abundant class of clone-specific RNA sequences, but these sequences were also found in about 10 -fold lower amounts in another variant. These results differ from ours. The difference could either be due to the use of other variants or to the low purity of the cDNA used as probe.

The cDNA clones characterized here have been used to obtain more information about the mechanism of antigenic variation. These results will be reported elsewhere.

\section{ACKNOWLEDGEMENTS}

We are indebted to the following persons for help with the experiments: Mr. A. Bernards, Mrs. H.A.M. Hoeijmakers-Van Dommelen and Dr. A.C.C. Frasch (University of Amsterdam), Mrs. Els de Groot (Central Laboratory of The Netherlands Red Cross Blood Transfusion Service, Amsterdam), Dr. H.H.M. Dahl (National Institute for Medical Research, London, U.K.), Mrs. Lynne Davey (The Wellcome Research Laboratories) and Dr. S. Nagata (University of Zurich) and to Dr. D. Kioussis (Temple University, Philadelphia, PA, USA) for providing the protocol for mRNA selection by hybridization with filter-bound DNA. This work was supported in part by a grant to P.B. from the Foundation for Fundamental Biological Research (BION), which is subsidized by The Netherlands Organization for the Advancement of Pure Research (ZWO), by a short-term fellowship from the European Molecular Biology Organization (EMBO) to J.H.J.H. and by a grant to C.W. of the Schweizerische Nationalfonds.

\section{REFERENCES}

Aarden, L.A., de Groot, E.R. and Feltkamp, T.E.W., Immunology of DNA, III. Crithidia luciliae, a simple substrate for the determination of anti-dsDNA with the immunofluorescence technique, Ann. N.Y. Acad. Sci., 254 (1975) 505-515.

Alwine, J.C., Kemp, D.J. and Stark, G.R., Method for detection of specific RNAs in agarose gels by transfer to diazobenzyloxymethyl-paper and hybridization with DNA probes, Proc. Natl. Acad. Sci. USA, 74 (1977) 5350-5354.

Bolivar, F., Rodriguez, R.L., Greene, P.J., Betlach, M.C., Heyneker, H.L. and Boyer, H.W., Construction and characterization of new cloning vehicles, II. A multipurpose cloning system, Gene, 2 (1977) 95-113. 
Bollum, F.J., Deoxynucleotide polymerizing enzymes from calf thymus gland, in Grossman, L. and Moldave, K. (Eds.), Methods in Enzymology, Vol. 12B, Academic Press, New York, 1968, pp. 591-611.

Bridgen, P.J., Cross, G.A.M. and Bridgen, J., N-terminal amino acid sequences of variantspecific surface antigens from Trypanosoma brucei, Nature, 263 (1976) 613-614.

Burrell, C.J., Mackay, P., Greenaway, P.J., Hofschneider, P.H. and Murray, K., Expression in Escherichia coli of hepatitis B virus DNA sequences cloned in plasmid pBR322, Nature 279 (1979) 43-47.

Capbern, A., Giroud, C., Baltz, T. and Mattern, P., Trypanosoma equiperdum: Etude des variations antigéniques au cours de la trypanosome expérimentale du lapin, Exp. Parasitol., 42 (1977) 6-13.

Chang, A.C.Y., Nunberg, J.H., Kaufman, R.J., Ehrlich, H.A., Schimke, R.T. and Cohen, S.N., Phenotypic expression in Escherichia coli of a DNA sequence coding for mouse dihydrofolate reductase, Nature, 275 (1978) 617-625

Clarke, L. and Carbon, J., Biochemical construction and selection of hybrid plasmids containing specific segments of the Escherichia coli genome, Proc. Natl. Acad. Sci. USA, $72(1975) 4361-4365$.

Cross, G.A.M., Identification, purification and properties of clone-specific glycoprotein antigens constituting the surface coat of Trypanosoma brucei, Parasitology, 71 (1975) $393-417$.

Cross, G.A.M., Antigenic variation in trypanosomes, Proc. Roy. Soc. London Ser. B, 202 (1978) 55-72.

Cross, G.A.M., Immunochemical aspects of antigenic variation in trypanosomes, J. Gen. Microbiol., 113 (1979) 1-11.

Denhardt, D.T., A membrane-filter technique for the detection of complementary DNA, Biochem. Biophys. Res. Commun., 23 (1966) 641-646

Dunninck, W., Joining immunoglobulin genes, Nature, 281 (1979) 253-254.

Eggitt, M.J., Tappenden, L. and Brown, K.N., Translation in a reticulocyte cell-free system of RNA isolated from blood and culture forms of Trypanosoma brucei, Parasitology, 75 (1977) 133-141.

Fairlamb, A.H., Weislogel, P.O., Hoeijmakers, J.H.J. and Borst, P., Isolation and characterization of kinetoplast DNA from bloodstream form of Trypanosoma brucei, J. Cell Biol., 76 (1978) 293-309.

Goldbach, R.W., Borst, P., Bollen-De Boer, J.E. and Van Bruggen, E.F.J., The organization of ribosomal RNA genes in the mitochondrial DNA of Tetrahymena pyriformis strain ST, Biochim. Biophys. Acta, 521 (1979) 169-186.

Gordon, J.I., Burns, A.T.H., Christmann, J.L. and Deeley, R.G., Cloning of a doublestranded cDNA that codes for a portion of chicken preproalbumin, J. Biol. Chem., 253 (1978) 8629-8639.

Gray, A.R., Antigenic variation in a strain of Trypanosoma brucei transmitted by Glossina morsitans and G. palpalis, J. Gen. Microbiol., 41 (1965) 195-214.

Grunstein, M. and Hogness, D.S., Colony hybridization: A method for the isolation of cloned DNAs that contain a specific gene, Proc. Natl. Acad. Sci. USA, 72 (1975) 3961-3965.

Hoeijmakers, J.H.J. and Borst, P., RNA from the insect trypanosome Crithidia luciliae contains transcripts of the maxi-circle and not of the mini-circle component of kinetoplast DNA, Biochim. Biophys. Acta, 521 (1978) 407-411.

Johnson, J.G. and Cross, G.A.M., Carbohydrate composition of variant-specific surface antigen glycoproteins from Trypanosoma brucei, J. Protozool,, 24 (1977) 587-591.

Johnson, J.G. and Cross, G.A.M., Selective cleavage of variant surface glycoproteins from Trypanosoma brucei, Biochem. J., 178 (1979) 689-697.

Kessler, S.W., Rapid isolation of antigens from cells with a Staphylococcal protein Aantibody adsorbent: Parameters of the interaction of antibody-antigen complexes with protein A, J. Immunol., 115 (1975) 1617-1624. 
Kleisen, C.M., Borst, P. and Weijers, P.J., The structure of kinetoplast DNA. I. Properties of the intact multi-circular complex from Crithidia luciliae, Biochim. Biophys. Acta, 390 (1975) 155-167.

Laemmli, U.K., Cleavage of structural proteins during the assembly of the head of bacteriophage T4, Nature, 227 (1970) 680-685.

Lheureux, M., Lheureux, M., Vervoort, T., Van Meirvenne, N. and Steinert, M., Immunological purification and partial characterization of variant-specific surface antigen messenger RNA of Trypanosoma brucei brucei, Nucl. Acids Res., 7 (1979) 595-609.

Maxwell, I.H., Maxwell, F. and Hahn, W.E., Removal of RNase activity from DNase by affinity chromatography on agarose-coupled aminophenylphosphoryl-uridine-2' $\left(3^{\prime}\right)$ phosphate, Nucl. Acids Res., 4 (1977) 241-246.

McDonell, M.W., Simon, M.N. and Studier, F.W., Analysis of restriction fragments of T7 DNA and determination of molecular weights by electrophoresis in neutral and alkaline gels, J. Mol. Biol., 110 (1977) 119-146.

Nantulya, V.M. and Doyle, J.J., Stabilization and preservation of the antigenic specificity of Trypanosoma (Trypanozoon) brucei variant specific surface antigens by mild fixation techniques, Acta Trop., 34 (1977) 313-320.

Newton, B.A. and Burnett, J.K., DNA of kinetoplastidae: A comparative study, in: Van den Bossche, H. (Ed.), Comparative Biochemistry of Parasites, Academic Press, New York, 1972, pp. 185-198.

Opperdoes, F.R., Aarsen, P.N., Van der Meer, C. and Borst, P., Trypanosoma brucei: An evaluation of salicylhydroxamic acid as a trypanocidal drug, Exp. Parasitol., 40 (1976) 198-205.

Paucha, E., Harvey, R. and Smith, A.E., Cell-free synthesis of Simian Virus 40 T-antigens, J. Virol., 28 (1978) 154-170.

Pawson, T., Martin, G.S. and Smith, A.E., Cell-free translation of virion RNA from nondefective and transformation-defective Rous Sarcoma Viruses, J. Virol., 19 (1976) 950-967.

Pelham, H.R.B. and Jackson, R.J., An efficient mRNA-dependent translation system from reticulocyte lysates, Eur. J. Biochem., 67 (1976) 247-256.

Penman, S., RNA metabolism in the HeLa cell nucleus, J. Mol. Biol., 17 (1966) 117-130.

Rigby, P.W.J., Dieckman, M., Rhodes, C. and Berg, P., Labeling deoxyribonucleic acid to high specific activity in vitro by nick translation with DNA polymerase I, J. Mol. Biol., 113 (1977) 237-251.

Southern, E.M., Detection of specific sequences among DNA fragments separated by gel electrophoresis, J. Mol. Biol., 98 (1975) 503-517.

St. John, T.P. and Davis, R.W., Isolation of galactose-inducible DNA sequences from Saccharomyces cerevisiae by differential plaque filter hybridization, Cell, 16 (1979) $443-452$.

Taniguchi, T., Palmieri, M. and Weissmann, C., Q $\beta$ DNA-containing hybrid plasmids giving rise to $Q \beta$ phage formation in the bacterial host, Nature, 274 (1978) 223-228.

Van den Berg, J., Van Ooyen, A., Mantei, N., Schamböck, A., Grosveld, G., Flavell, R.A. and Weissmann, C., Comparison of cloned rabbit and mouse $\beta$-globin genes showing strong evolutionary divergence of two homologous pairs of introns, Nature, 276 (1978) $37-44$

Van Ommen, G.J.B., Groot, G.S.P. and Grivell, L.A., Transcription maps of mtDNAs of two strains of Saccharomyces: Transcription of strain-specific insertions; complex RNA maturation and splicing, Cell, 18 (1979) 511-523.

Vickerman, K., Antigenic variation in trypanosomes, Nature, 273 (1978) 613-617.

Villa-Komaroff, L., Efstratiadis, A., Broome, S., Lomedico, P., Tizard, R., Naber, S.P., Chick, W.L. and Gilbert, W., A bacterial clone synthesizing proinsulin, Proc. Natl. Acad. Sci. USA, 75 (1978) 3727-3731.

Weislogel, P.O., Hoeijmakers, J.H.J., Fairlamb, A.H., Kleisen, C.M. and Borst, P., Character- 
ization of kinetoplast DNA networks from the insect trypanosome Crithidia luciliae, Biochim. Biophys. Acta, 478 (1977) 167-179.

Weissmann, C. and Boll, W., Reduction of possible hazards in the preparation of recombinant plasmid DNA, Nature, 261 (1976) 428-429.

Wiegand, R.C., Godson, G.N. and Radding, C.M., Specificity of the $S_{1}$ nuclease from Aspergillus oryzae, J. Biol. Chem., 250 (1975) 8848-8855.

Wilkie, N.M., Clements, J.B., Boll, W., Mantei, N., Lonsdale, D. and Weissmann, C., Hybrid plasmids containing an active thymidine kinase gene of herpes simplex virus 1 , Nucl. Acids Res., 7 (1979) 859-877.

Williamson, R.O., Marcu, K.B., Young, J.R., Rovis, L. and Williams, S.C., A characterization of mRNA activities and their sequence complexities in Trypanosoma brucei Partial purification and properties of the VSSA mRNA, Nucl. Acids Res., 5 (1978) 3171-3182.

Communicated by W. Szybalski. 